\title{
Social security benefits
}

\section{Ronald L. Plain \\ Department of Agricultural Economics \\ College of Agriculture}

The Social Security system is the primary retirement and disability program for millions of Americans. Yet most people know very little about the full range of benefits available from social security. This guide sheet is intended to provide an introduction to social security benefits and explain changes made in 1983. It is not intended to replace professional advice. For answers to specific questions about social security benefits, contact the Social Security Administration.

\section{Who receives social security benefits?}

Social security benefits are related to social security taxes paid. (For information on social security taxes see UMC Guide 480, "Social security taxes and tax management," or contact any social security office.)

In general, social security benefits are available to workers (and sometimes their family members) who have paid social security taxes long enough to have received a certain minimum number of credits. Social security credits are called "quarters of coverage."

The procedure for determining quarters of coverage was changed in 1984. Prior to 1984, employees received one quarter of credit for each calendar quarter in which they earned taxable wages of $\$ 50$ or more. Self-employed individuals received four quarters of coverage credit for each calendar year in which they reported a net profit of $\$ 400$ or more.

For 1984, workers earn one quarter of coverage for each $\$ 390$ of annual earnings, up to a maximum of four quarters per year. The $\$ 390$ amount will increase each year as average earnings increase.
Social security benefits may be reduced if an individual receives other benefits paid by federal, state, or local government programs.

\section{Benefits available from social security}

Monthly social security checks go to workers and their dependents when the worker retires, becomes severely disabled, or dies. Benefits can be classed in four categories: retirement; disability; dependents and survivors; and Medicare.

\section{Retirement benefits}

To receive retirement benefits, you must have at least as many quarters of coverage as shown in Table 1. Persons born after 1928 need 40 quarters of coverage in order to receive social security retirement benefits. An exception is made for certain employees of nonprofit organizations.

\begin{tabular}{cc} 
& \multicolumn{2}{c}{ Table 1 } \\
Work credits needed for retirement benefits
\end{tabular}


If you have paid social security taxes long enough to qualify for retirement benefits, the amount which you will receive upon retirement is determined by the amount of social security taxes you paid, your age when you start receiving benefits, and the year you were born. (See Table 2.)

You cannot begin receiving social security retirement benefits before age 62 . As Table 2 indicates, if you retire at age 62 (prior to the year 2000), your monthly retirement check will be equal to 80 percent of what you would receive had you worked to age 65 .

The size of your check is set when you start receiving benefits. For workers who retire in 1984, the maximum monthly benefit is $\$ 703$ for workers who are 65 , and $\$ 559$ for workers who are 62 . Very few people qualify for the maximum.

There is no fixed minimum payment. Social security benefits are indexed to the cost of living, and your check may increase.

Until the year 2000, retirement benefits increase by five-ninths of a percentage point for each month you work past your 62nd birthday, up to age 65 .

Persons who work beyond age 65 receive a credit for each month they work past age 65. For persons born before 1917 the credit is 1 percent per year. For persons born after 1916, the credit is 3 percent per

\section{Table 2}

Percent of full retirement benefits received

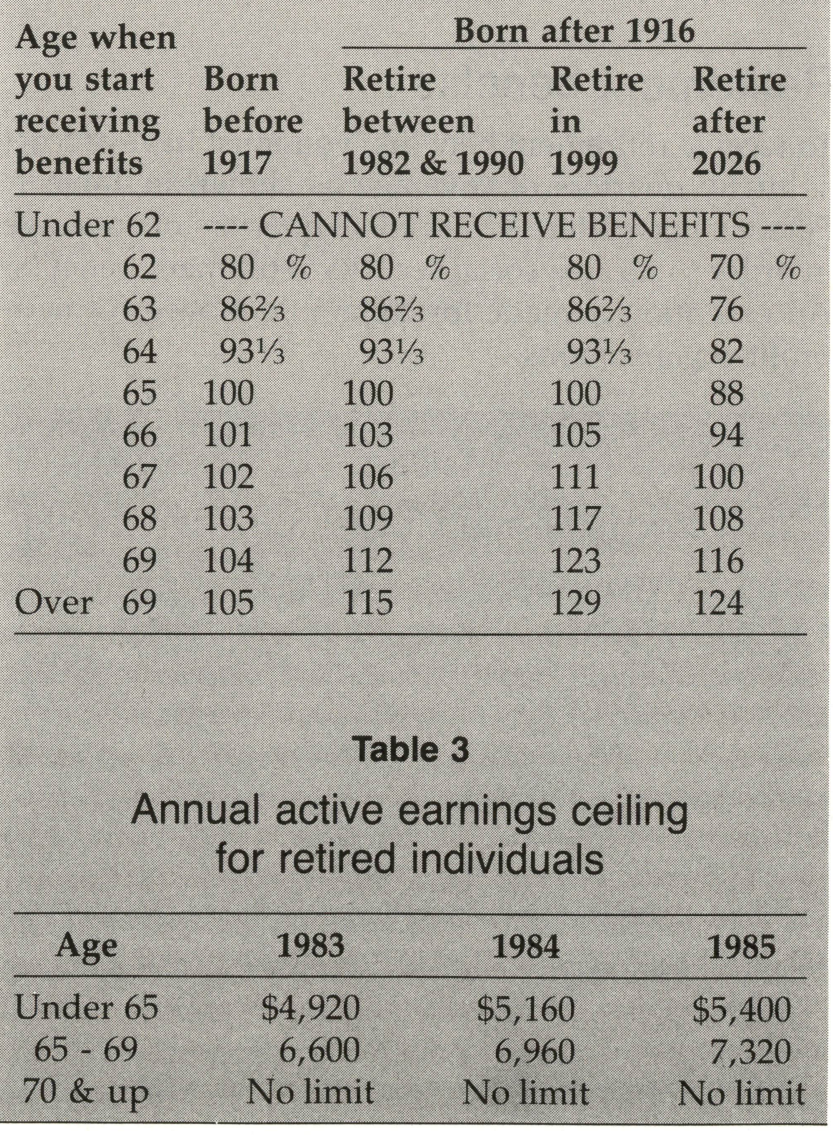

year if they retire between 1982 and 1990. Beginning in 1990, the credit is scheduled to increase gradually until it reaches 8 percent per year in 2008 .

Beginning in 2000, the full benefit retirement age will gradually increase until it reaches 67 in 2027.

\section{Penalty for working}

Once you begin receiving social security retirement benefits, you may be penalized if you continue to work. You may receive limited "active earnings" without having your social security retirement check reduced. (See Table 3.) This limit is indexed to average wages and is adjusted each year.

When an individual reaches age 70, the earnings ceiling is removed. You then have no limit on earnings while still receiving your social security benefits.

If your active earnings go above the amounts shown in Table 3, one dollar will be deducted from your social security retirement check for each $\$ 2$ you earn above the limit. If a deduction is not made, you will have to repay social security for any amount you are overpaid. Beginning in 1990, the deduction rate for people 65 and older will become one dollar for each $\$ 3$ of active earnings above the limit.

\section{What are active earnings?}

Active earnings include all wages paid to you as an employee plus any net earnings from self-employment for which you perform substantial services.

Retired farmers need to be particularly careful about any farm earnings they may have. Normally, rental income does not count as active earnings. However, rental income or benefits from government commodity programs will count as active earnings if you are "materially participating" in the farm business. The Internal Revenue Service gives four tests for material participation. Your farm income will be considered to be active earnings if you meet any one of the tests.

Test 1. You do any three of the following: (1) advance, pay, or stand good for at least half the direct costs of producing the crop; (2) furnish at least half the tools, equipment, and livestock used in production; (3) consult with your tenant; and (4) inspect the production activities periodically.

Test 2. You regularly and frequently take an important part in making management decisions substantially affecting the success of the enterprise.

Test 3. You work 100 hours or more spread over a period of five weeks or more in activities connected with crop production. Work performed under a separate agreement as an employee of your tenant does not count.

Test 4. You do things which, considered in their total effect, show you are materially and significantly involved in the production of the farm commodities. 


\section{Disability benefits}

You must pay social security taxes for a certain period before you become eligible for disability benefits. If you become disabled before reaching age 24, you will need a minimum of six quarters of coverage during the three year period immediately prior to becoming disabled in order to be eligible for social security disability benefits. If you are between the ages of 24 and 31 you will need two quarters of coverage for each year between age 21 and when you become disabled. If you become disabled between ages 31 and 42 , you will need 20 quarters of credit to receive disability benefits.

Persons who were born after 1929 and become disabled between ages 42 and 62 need 20 quarters of coverage plus one additional quarter for each year between age 42 and when they become disabled. Persons who were born before 1930 and become disabled before age 62 need 30 quarters of coverage plus one additional quarter for each year between 1981 and when they become disabled. Disabled workers over age 30 need at least 20 quarters of credit during the previous 10 years to be eligible. Persons disabled by blindness can receive disability benefits with fewer credits.

If you have sufficient credits, social security will pay benefits if you become disabled. To be considered disabled, you must have a physical or mental condition which prevents you from doing any substantial gainful work for at least 12 months, or is expected to result in death.

\section{Benefits your family may receive}

Your family may receive a number of benefits if you are covered by social security. These benefits are available to family members regardless of whether they paid social security taxes.

If you are receiving social security disability or retirement benefits, or if, at your death, you are covered by social security, your children may be entitled to monthly checks if they are unmarried and:

- under 18; or

- 18 and still in high school; or

- were severely disabled before age 22; or

- under 22 and have been a full-time college student since May, 1982, and have been eligible since August, 1981.

If you are receiving social security retirement or disability benefits your spouse may also be entitled to monthly checks if he or she is age 62 or over, or is under 62 and is caring for a child under 16 (or disabled) who is receiving checks on your record.

Benefits to a family member of a worker receiving social security benefits may be reduced if either that family member's earnings exceed $\$ 5,160$ (in 1984) or the retired worker's actual earnings exceed the limits given in Table 3. Benefits are reduced by one dollar for each two dollars earned over the limit.

If a covered worker dies, survivor's checks can go to certain family members. Monthly payments can be made to a deceased worker's:

- spouse if 60 or older; or

- spouse or surviving divorced mother or father if caring for worker's child under 16 (or disabled) who is getting a benefit based on the earnings of the deceased worker; or

- spouse if 50 or older who becomes disabled within seven years after worker's death or within seven years after mother's or father's benefits end; or

- dependent parents if 62 or older.

Checks can also go to a divorced spouse age 62 or older, a surviving divorced spouse at 60 , or to a disabled surviving divorced spouse at 50 if the marriage lasted 10 years or longer.

Under certain conditions, children may be eligible for social security benefits based on a grandparent's earnings.

If an individual qualifies for benefits on the record of more than one worker (for example, your own and your spouse's), he or she will receive the larger of the two amounts.

\section{Medicare}

Medicare is a health insurance program for persons with permanent kidney failure, persons over age 64, or persons who have received social security disability benefits for 24 months or more. It provides hospital insurance and medical insurance. The hospital insurance is financed through part of the social security tax. It is available to people age 65 or older who are entitled to social security, civil service, or railroad retirement benefits. The medical insurance is financed by a combination of monthly premiums paid by the individual and general revenues from the federal government. No work credits are needed for Medicare medical insurance.

\section{Taxes on your social security benefits}

Prior to 1984, social security benefits were not taxable. Beginning in 1984, up to half of your social security benefits may be included in your taxable income. If your adjusted gross income plus your non-taxable interest income, plus half your social security benefits exceeds $\$ 25,000$ for single individuals or $\$ 32,000$ for married filing jointly, a portion of your social security benefits will be taxable.

\section{Social security: Not a savings plan}

Social security is not a savings program. Social security taxes collected are paid out immediately to others in benefits. Since it is not actuarially sound, it is not an insurance program. 
Social security takes income from workers and gives it to the retired and disabled. The amount taken-social security taxes-and the amount givensocial security benefits-is dependent on the relative size of these two groups. Predicting their future size with accuracy is difficult. Both will continue to change. Social security should not be your only retirement or disability program. All individuals should develop a personal savings-insurance plan.

\section{Additional information}

For additional information on the Social Security system, see UMC Guide 480, "Social security taxes and tax management," or call, write, or visit any social security office. The address of the nearest office is listed in your telephone book under Social Security Administration.

Issued in furtherance of Cooperative Extension Work Acts of May 8 and June 30, 1914 in cooperation with the United States Department of Agriculture. Leonard C. Douglas, Director, Cooperative Extension Service, University of Missouri and Lincoln University, Columbia, Missouri 65211. An equal opportunity institution. 